\title{
PENGARUH SELF-DISCIPLINE DAN PENGETAHUAN TEORI SECARA LANGSUNG DAN MELALUI HASIL BELAJAR PRAKTIKUM PEMESINAN TERHADAP KESIAPAN MEMASUKI DUNIA KERJA SISWA SMK
}

\author{
Dwi Nurcahyo \\ Widiyanti \\ Wahono
}

\begin{abstract}
Abstrak: Tujuan penelitian untuk mengetahui pengaruh self-discipline dan pengetahuan teori pemesinan secara langsung dan melalui hasil belajar praktikum pemesinan terhadap kesiapan memasuki dunia kerja siswa SMK. Penelitian ini dilaksanakan di Sekolah Menengah Kejuruan dengan sampel sebanyak 86 siswa. Pengumpulan data menggunakan kuesioner dan dokumentasi. Data dianalisis menggunakan jalur dengan taraf signifikansi 0,05. Hasil penelitian menunjukkan: (1) tidak ada berpengaruh langsung self-discipline terhadap hasil belajar praktikum pemesinan tetapi ada pengaruh langsung terhadap kesiapan memasuki dunia kerja; (2) ada berpengaruh langsung pengetahuan teori pemesinan terhadap hasil belajar praktikum pemesinan dan kesiapan memasuki dunia kerja; dan (3) tidak ada pengaruh tidak langsung self-discipline dan pengetahuan teori pemesinan, melalui hasil belajar praktikum pemesinan, terhadap kesiapan memasuki dunia kerja.
\end{abstract}

Kata-kata Kunci: self-discipline, teori pemesinan, hasil praktikum, kesiapan kerja

Abstract: The Effect of Self-Discipline and Theoretical Knowledge, Directly and Through the Learning Outcomes of the Machinery Practicum, on Vocational High School Student Readiness for Work Employment. The study aimed to determine the contribution of self-discipline and theoretical knowledge of machining practicum learning outcomes and their impact on the students' readiness for work employment. This research uses 86 students as the samples. Data was analyzed using path analysis. The results showed that: (1) self-discipline has no direct significant effect of on the learning outcome of the machinery practicum, but it has direct significant effect on the students readiness for work employment; (2) there is a direct significant effect of theoretical knowledge on the learning outcomes of machining practicum and students readiness for work employment; and (3) there is no indirect effect of self-discipline and theoretical knowledge, through the learning outcome of machining practicum, on the students readiness for work employment.

Keywords: self-discipline, machining theory, the result of lab work, the readiness of work

yang mempersiapkan siswa untuk bekerja (SMK) sebagai lembaga pendidikan nampaknya tidak sesuai dengan kenyataan

Dwi Nurcahyo adalah Mahasiswa PPG Prajabatan Universitas Negeri Malang. Email: cayoexcited@gmail.com. Widiyanti dan Wahono adalah Dosen Jurusan Teknik Mesin Universitas Negeri Malang. Alamat Kampus: Jl. Semarang No. 5 Malang 65145. 
yang ada. Hal tersebut dibuktikan dari Badan Pusat Statistik (2015) data temuan Badan Pusat Statistik (BPS) yang melaporkan bahwa jumlah pengangguran di Indonesia pada Agustus 2015 sebanyak 7,56 juta jiwa. Seperti yang dijabarkan pada Undang-undang RI No 20 Tahun 2003 tentang Sistem Pendidikan Nasional pada pasal 15 yang berbunyi pendidikan kejuruan merupakan pendidikan menengah yang mempersiapkan peserta didik terutama untuk bekerja dalam bidang tertentu, baik bekerja secara mandiri (wiraswasta) maupun mengisi lowongan yang ada. (Depdiknas, 2003) Sejumlah kegiatan diberlakukan di SMK guna mempersiapkan siswanya dalam bekerja, seperti praktik kerja industri (prakerin), unit produksi dan lain sebagainya yang diharapkan mampu mengasah keahlian siswa agar terbiasa bekerja dengan kondisi dunia kerja sebenarnya.

Berdasarkan data awal yang didapatkan dari Bursa Kerja Khusus (BKK) SMK Negeri 6 Malang, terjadi peningkatan lulusan yang belum bekerja sebanyak 40,00\% sepanjang tahun 2013 sampai 2016. Siswa yang belum bekerja selama periode 2013/2014 sebanyak $11,00 \%$ dan pada periode $2014 / 2015$ sebanyak $16,00 \%$, sedangkan pada periode 2015/2016 meningkat menjadi 51,00\%. Untuk lulusan teknik pemesinan pada periode $2013-2014$ terdapat $15,00 \%$ yang belum bekerja dan meningkat pada periode 2015-2016 sebanyak 51,00\%.

Hasil wawancara dengan sejumlah siswa di SMK Negeri 6 Kompetensi Keahlian Teknik Pemesinan, kebanyakan siswa menyatakan telah siap untuk memasuki dunia kerja, namun tidak sedikit pula yang menyatakan belum siap dalam bekerja karena kurangnya penguasaan mata pelajaran Teknik Pemesinan, serta minimnya pengetahuan terkait dunia kerja. Padahal tantangan dunia kerja abad ini semakin ketat. Pasalnya sejak tahun 2015 hingga saat ini Indonesia telah menerap- kan bentuk persaingan kawasan bebas perdagangan dalam rangka meningkatkan daya saing ekonomi kawasan ASEAN atau yang disebut dengan Asean Free Trade Area (AFTA). Untuk itu perlu adanya pemantapan generasi penerus bangsa guna menghadapi persaingan yang semakin menantang. Dalam hal ini SMK sebagai lembaga pendidikan kejuruan yang bertujuan untuk mencetak lulusan yang sesuai dengan tuntutan dunia kerja perlu mengambil langkah jitu dalam mengatasi permasalahan kesiapan siswanya dalam bekerja.

Berdasarkan hasil temuan Wibowo (2015:49) mensinyalir bahwa langkah konkrit yang dapat dilakukan SMK dalam mencetak lulusan yang berkompeten yaitu dengan cara menyiapkan tenaga kerja dari segi hardskill maupun soft skill. Namun kenyataan dilapangan SMK belum sepenuhnya menerapkan langkat tersebut terlebih dari segi soft skill. $\mathrm{Pa}-$ dahal tujuan dari pendidikan karakter dalam kurikulum 2013 adalah untuk meningkatkan mutu proses dan hasil pendidikan, yang mengarah pada pembentukan budi pekerti dan akhlak mulia peserta didik secara utuh, terpadu, dan seimbang (Mulyasa, 2015:7).

Berdasarkan identifikasi masalah di atas timbul pertanyaan yaitu faktor-faktor apa yang mempengaruhi kesiapan siswa dalam memasuki dunia kerja. Amanat Pemerintah Republik Indonesia tentang desain induk pembangunan karakter bangsa 2015-2025 yaitu karakter yang bersumber dari olah hati yang meliputi beriman dan bertakwa, bersyukur, jujur, amanah, adil, tertib, sabar, disiplin, taat aturan, bertanggung jawab, berempati, punya rasa iba (compassion), berani mengambil resiko, pantang menyerah, menghargai lingkungan, rela berkorban dan berjiwa politik.

Menurut Amri, dkk. (2011:42) mendefinisikan disiplin diri (self-discipline) sebagai upaya mendemonstrasikan kerja 
keras, mengendalikan emosi, kata-kata, tindakan dan keinginan untuk memberikan yang terbaik dalam segala sesuatu. Artinya disiplin diri ini berkaitan dengan proses pendewasaan diri siswa dalam mengkonsep pola berfikirnya menuju pribadi yang siap menatap masa depan.

Adapun tujuan dari disiplin diri adalah untuk mengembangkan minat anak dan mengembangkan anak menjadi manusia yang baik, yang akan menjadi sahabat, tetangga, dan warga negara yang baik (Benhard dalam Shochib, 2000:3). Selain itu sikap disiplin mampu menjaga seseorang agar setiap tindakan yang dilakukan tetap berada pada jalan menuju tujuan akhir yang ingin dicapai, bahkan mampu untuk menjaga tujuan akhir itu sendiri. Kedisiplinan akan terbangun dengan niat yang kuat, motivasi yang utuh dan sungguh-sungguh, serta kesadaran akan alasan dari penetapan tujuan akhir yang ingin dicapai. Sementara sikap tidak disiplin akan menjadikan jalan menuju tujuan akhir semakin jauh dan berliku, karena sikap tidak konsisten yang akan mendatangkan malapetaka bagi diri sendiri maupun orang lain, semisal mereka yang tidak disiplin dengan mekanisme Standard Operating Procedure (SOP) yang ditetapkan oleh perusahaan melalui K3 (Kesehatan dan Keselamatan Kerja), dalam pekerjaannya akan mendatangkan kecelakaan kerja yang dapat membahayakan diri sendiri dan orang lain (Saleh, 2012:298).

Selain dari pada itu faktor lain yang ikut berperan adalah dari segi hard skill yang mana terbagi dalam dua cabang yaitu teori dan praktik. Pengetahuan teori pemesinan dalam penelitian ini adalah tingkat pemahaman siswa terhadap teori mata pelajaran teknik pemesinan yang digunakan sebagai dasar dalam melaksanakan mata pelajaran praktikum pemesinan. Snelbecker (dalam Dahar, 2011:12) mengartikan teori sebagai sejumlah proporsi yang terintregrasi secara sintaktik dan dapat digunakan untuk memprediksi dan menjelaskan peristiwa-peristiwa yang diamati. Kumpulan proporsi disini artinya mengikuti aturan-aturan tertentu yang dapat menghubungkan secara logis antara proporsi yang satu dengan proporsi yang lain, dan juga pada data yang diamati.

Suatu teori dan praktik dalam dunia pendidikan dapat dilihat dari hasil belajar yang telah dicapai oleh siswa. Adapun yang dimaksud hasil belajar menurut Nurhayati (2015:174) adalah perubahan tingkah laku karena adanya usaha atau pembelajaran yang meliputi pengetahuan, keterampilan dan sikap. Namun yang dimaksud dengan perubahan tingkah laku secara keseluruhan bukan hanya pada salah satu aspek potensi kemanusiaan saja, artinya hasil pembelajaran tidak dilihat secara terpisah (fragmentasi) melainkan harus komperhensif. Hal tersebut didasarkan atas pemikiran para pakar pendidikan seperti Gagne (1965) yang merumuskan hasil belajar berupa hal-hal sebagai berikut: (1) informasi verbal; (2) keterampilan intelektual; (3) strategi kognitif; (4) keterampilan motorik; dan (5) sikap. Sedangkan menurut Lindgren hasil pembelajaran meliputi kecakapan, informasi, pengertian, dan sikap. Dalam penelitian ini hasil belajar praktikum pemesinan merupakan hasil yang telah dicapai oleh siswa dalam melaksanakan kegiatan pembelajaran pada mata pelajaran Praktikum Pemesinan.

Mata Pelajaran Teori Pemesinan dan Praktikum pemesinan termasuk ke dalam kompetensi akademik produktif yang haruslah dikuasai oleh siswa SMK bidang pemesinan, sedangkan selfdiscipline merupakan salah satu jenis kepribadian dalam pendidkan berkarakter yang berorientasi pada soft skill siswa. Peneltian Rizkiansyah (2016) membuktikan bahwa terdapat hubungan yang positif dan signifikan secara simultan antara sikap kerja (soft skill) siswa dan 
kompetensi kejuruan terhadap kesiapan kerja di Industri dengan nilai korelasi sebesar 0,186 . Penelitian tersebut sejalan dengan penjelasan Hariyanto, dkk. (2015: 42) yang mengungkapkan bahwa seorang siswa mempunyai kesiapan kerja apabila siswa tersebut memiliki kemampuan yang mencangkup aspek sikap, pengetahuan, dan keterampilan.

Penelitian ini bertujuan untuk mengetahui besarnya pengaruh self-discipline dan pengetahuan teori pemesinan secara dan melalui hasil belajar mata pelajaran Praktikum Pemesinan terhadap kesiapan memasuki dunia kerja siswa SMKN. Diharapkan hasil penelitian ini dapat dijadikan bahan informasi dan kajian bagi pihak-pihak yang berhubungan dengan penelitian ini seperti lembaga sekolah, pendidik, peserta didik maupun masyarakat untuk selalu memperhatikan faktor-faktor yang mempengaruhi kesiapan siswa dalam memasuki dunia kerja sebagai upaya penyiapan sumber daya manusia yang berkualitas.

\section{METODE}

Penelitian ini menggunakan pendekatan analisis jalur. Perolehan besarnya koefisien jalur menggunakan metode perhitungan koefisien regresi baku (beta, $\beta$ ) berbantuan aplikasi SPSS 22. Gambaran hubungan antar variabel, terlihat pada Gambar 1.

Penentuan responden dalam penelitian ini akan mengambil seluruh siswa kelas XII Kompetensi Keahlian Teknik Pemesinan di SMK Negeri 6 Malang sejumlah 86 secara random. Terdapat dua metode yang digunakan untuk mengumpulkan data, yaitu metode kuesioner dan metode dokumentasi. Data yang dikumpulkan berskala interval. Sebelum dianalisis dilakukan uji persyaratan, yaitu uji normalitas, linieritas, multikolinieritas, autokorelasi dan heteroskedastisitas.

Hasil pengujian normalitas didapatkan bahwa seluruh kurva distribusi berbentuk normal dengan nilai kolmogrov smirnov lebih dari 0,05. Hasil pengujian linieritas pada Tabel 1 diketahui bahwa nilai signifikansi dari masing-masing hubungan lebih dari 0,05 sehingga linieritas terpenuhi. Selanjutnya yaitu uji multikolinieritas yang mana dengan me-

Tabel 1. Hasil Uji Linieritas

\begin{tabular}{cccc}
\hline Model & Hubungan & Harga F & $\begin{array}{c}\text { Signifi- } \\
\text { kansi }\end{array}$ \\
\hline \multirow{2}{*}{ Kausal 1 } & $\mathrm{X} 1 \rightarrow \mathrm{Y}$ & 0,907 & 0,591 \\
& $\mathrm{X} 2 \rightarrow \mathrm{Y}$ & 3,031 & 0,280 \\
\hline \multirow{2}{*}{ Kausal 2 } & $\mathrm{X} 1 \rightarrow \mathrm{Z}$ & 1,323 & 0,190 \\
& $\mathrm{X} 2 \rightarrow \mathrm{Z}$ & 1,523 & 0,479 \\
& $\mathrm{Y} \rightarrow \mathrm{Z}$ & 0,865 & 0,662 \\
\hline
\end{tabular}

Tabel 2. Hasil Uji Multikolinieritas

\begin{tabular}{llr}
\hline Model & Variabel & VIF \\
\hline Jalur Kausal 1 & X1 & 1,034 \\
Variabel Terikat (Y) & X2 & 1,034 \\
\hline \multirow{2}{*}{ Jalur Kausal 2 } & X1 & 1,045 \\
Variabel Terikat (Z) & X2 & 2,197 \\
& Y & 2,215 \\
\hline
\end{tabular}

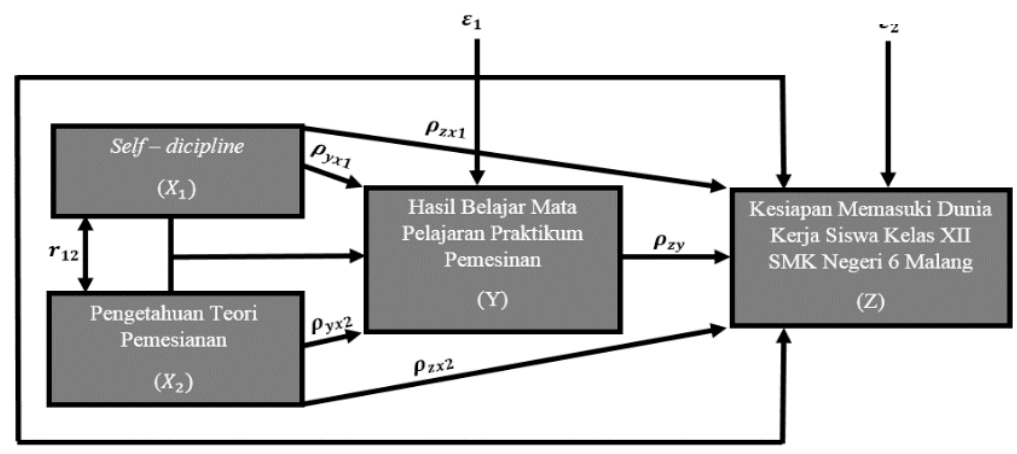

Gambar 1. Bagan Pengaruh X1 dan X2, Secara Langsung dan melalui Y terhadap Z 
lihat angka Variance Inflation Factor (VIF).

Berdasar uji multikolinieritas Tabel 2 diketahui bahwa seluruh nilai VIF dari variabel bebas lebih besar dari 5 sehingga dapat dinyatakan bahwa seluruh data variabel eksogenus bebas dari multikolinieritas. Pengujian selanjutnya yaitu uji autokorelasi menggunakan metode Durbin Watson untuk masing-masing jalur kausal.

Tabel 3. Hasil Uji Autokorelasi

\begin{tabular}{cccc}
\hline Model & R & R square & $\begin{array}{c}\text { Durbin - } \\
\text { Watson }\end{array}$ \\
\hline Jalur 1 & 0,741 & 0,548 & 1,964 \\
Jalur 2 & 0,597 & 0,357 & 1,781 \\
\hline
\end{tabular}

Tabel 4. Hasil Uji Heteroskedastisitas

\begin{tabular}{lccc}
\hline Model & Variabel & Nilai t & Signifikansi \\
\hline \multirow{2}{*}{ Jalur 1 } & $\mathrm{X} 1$ & 0,517 & 0,607 \\
& $\mathrm{X} 2$ & $-1,283$ & 0,203 \\
\hline \multirow{2}{*}{ Jalur 2 } & $\mathrm{X} 1$ & 0,346 & 0,730 \\
& $\mathrm{X} 2$ & $-1,863$ & 0,066 \\
& $\mathrm{Y}$ & 1,495 & 0,139 \\
\hline
\end{tabular}

Berdasarkan Tabel 3 hasil uji autokorelasi diketahui bahwa nilai Durbin Watson berada di antara dU dan $4-\mathrm{dU}$ sehingga autokorelasi tidak terjadi pada masing-masing jalur kausal. Pengujian yang terakhir yaitu heteroskedastisitas menggunakan metode park gleyser dengan meregresikan masing-masing variabel bebas terhadap nilai absolut residunya (e).

Berdasar hasil uji heteroskedastisitas Tebel 4, diketahui bahwa nilai signifikansi hubungan variabel bebas terhadap nilai absolut residunya berada di atas 0,05 dengan kata lain bahwa data variabel bebas terhindar dari heteroskedastisitas. Dalam pengujian hipotesis menggunakan metode analisis jalur yang mana bertujuan untuk mengungkapkan pengaruh langsung dan tidak langsung dari suatu variabel penyebab terhadap variabel akibat.

\section{HASIL}

Hasil analisis jalur pertama, pada sub struktur pertama ini akan mengulas diagram jalur pertama yang terdiri dari dua variabel eksogenus (X1 dan X2) terhadap variabel endogenus (Y) pada Gambar 2.

Langkah selanjutnya yaitu dengan meregresikan variabel eksogenus (X1 dan X2) dengan variabel endogenus (Y) secara simultan. Hal ini dilakukan sebagai syarat dikakukannya analisis regresi secara parsial yang nantinya. Adapun hasil regresi jalur pertama dapat dilihat pada Tabel 5.

Berdasar Table 5, dapat diketahui bahwa nilai signifikansi kurang dari 0,05 yaitu sebesar 0,000. Oleh karena hasil pengujian secara simultan menunjukkan angka yang signifikan, maka pengujian secara parsial dapat dilakukan. Hasil regresi secara parsial jalur pertama (Tabel 6) diketahui bahwa terdapat jalur yang tidak signifikan yaitu antara variabel

Tabel 5. Hasil Regresi Struktur Pertama

\begin{tabular}{lccc}
\hline \multirow{2}{*}{ Model } & \multicolumn{3}{c}{ Jalur 1 } \\
\cline { 2 - 4 } & Regression & Residual & Total \\
\hline Sum of & 436,692 & 359,48 & 796,172 \\
Square & 2 & 83 & 85 \\
$d f$ & & 4,331 & \\
Mean & 218,346 & & \\
Square & 50,414 & & \\
Nilai F & 0,548 & & \\
R Square & 0,000 & & \\
Sig. & 0 \\
\hline
\end{tabular}

Tabel 6. Hasil Regresi Parsial Jalur Pertama

\begin{tabular}{lcc}
\hline \multirow{2}{*}{ Model } & \multicolumn{2}{c}{ Jalur 1 } \\
\cline { 2 - 3 } & $\mathbf{X 1}$ & $\mathbf{X 2}$ \\
\hline B & 0,031 & 0,810 \\
Std. Error & 0,033 & 0,084 \\
Beta & 0,070 & 0,725 \\
Nilai $\mathrm{t}$ & 0,934 & 9,662 \\
Signifikansi & 0,353 & 0,000 \\
\hline
\end{tabular}


variabel self-discipline terhadap hasil belajar praktikum pemesinan, maka perlu dilakukan analisis ulang dengan menghilangkan jalur antara X1 terhadap Y.

Berdasarkan Tabel 7, hasil analisis ulang jalur 1, diketahui bahwa terjadi perubahan koefisien jalur (beta) yaitu sebesar 0,737 yang semula 0,725 .
Gambar 3. Langkah selanjutnya yaitu meregresikan variabel eksogenus dengan variabel endogenus secara simultan.

Hasil analisis regresi simultan (Tabel 8) nilai signifikansi menunjukkan angka $0,000<0,05$. Berdasarkan hasil analisis regresi simultan yang menunjukkan angka yang signifikan, maka analisis regresi

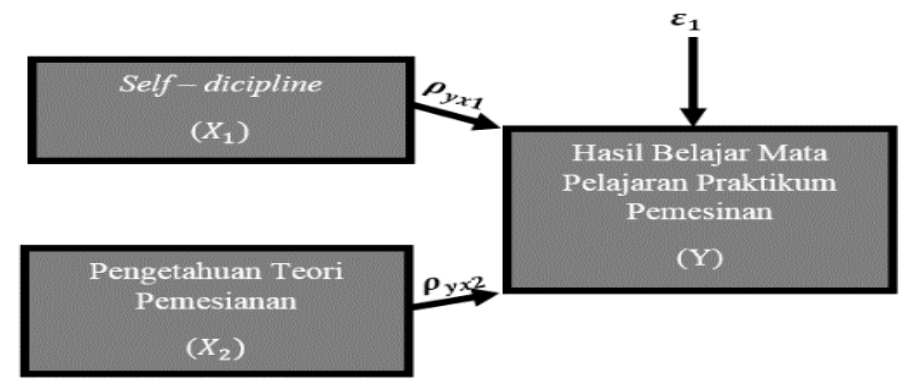

Gambar 2. Bagan Jalur Struktur Pertama

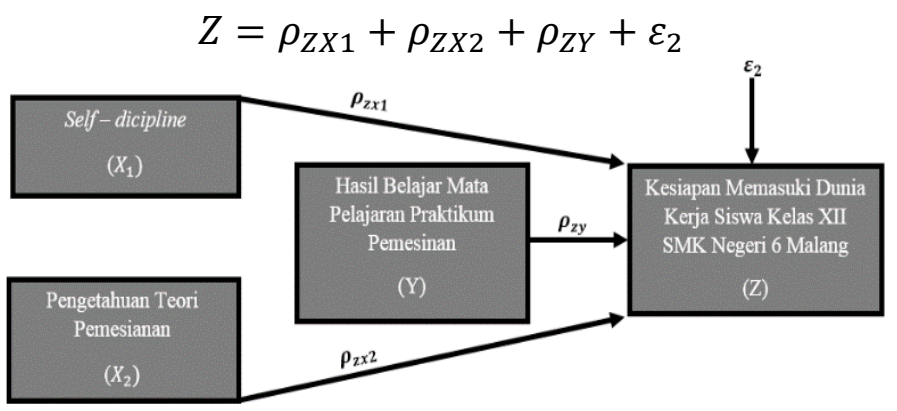

Gambar 3. Bagan Jalur Struktur Kedua

Hasil analisis jalur kedua, dalam jalur struktur kedua ini akan menguji pengaruh antara variabel eksogenus (X1, X2 dan Y) terhadap variabel endogenus (Z). Variabel Y berubah menjadi variabel eksogenus pada sub struktur kedua karena status variabel $\mathrm{Y}$ yang juga merupakan variabel intervening (antara) pada
Tabel 7. Hasil Regresi Parsial Jalur 1 Metode Trimming

\begin{tabular}{lc}
\hline \multicolumn{1}{c}{ Model } & $\mathbf{X 2} \rightarrow \mathbf{Y}$ \\
\hline$R$ square & 0,538 \\
Beta & 0,737 \\
Nilai $t$ & 10,005 \\
Signifikansi & 0,000 \\
\hline
\end{tabular}

\section{Tabel 8. Hasil Regresi Struktur Kedua}

\begin{tabular}{lccc}
\hline \multirow{2}{*}{ Model } & \multicolumn{3}{c}{ Jalur Kausal 2 } \\
\cline { 2 - 4 } & Regression & Residual & Total \\
\hline Sum of Square & 1301,046 & 2346,326 & 3648,372 \\
$d f$ & 3 & 82 & 85 \\
Mean Square & 434,015 & 28,614 & \\
Nilai F & 15,168 & & \\
R Square & 0,357 & & \\
Sig. & 0,000 & & \\
\hline
\end{tabular}



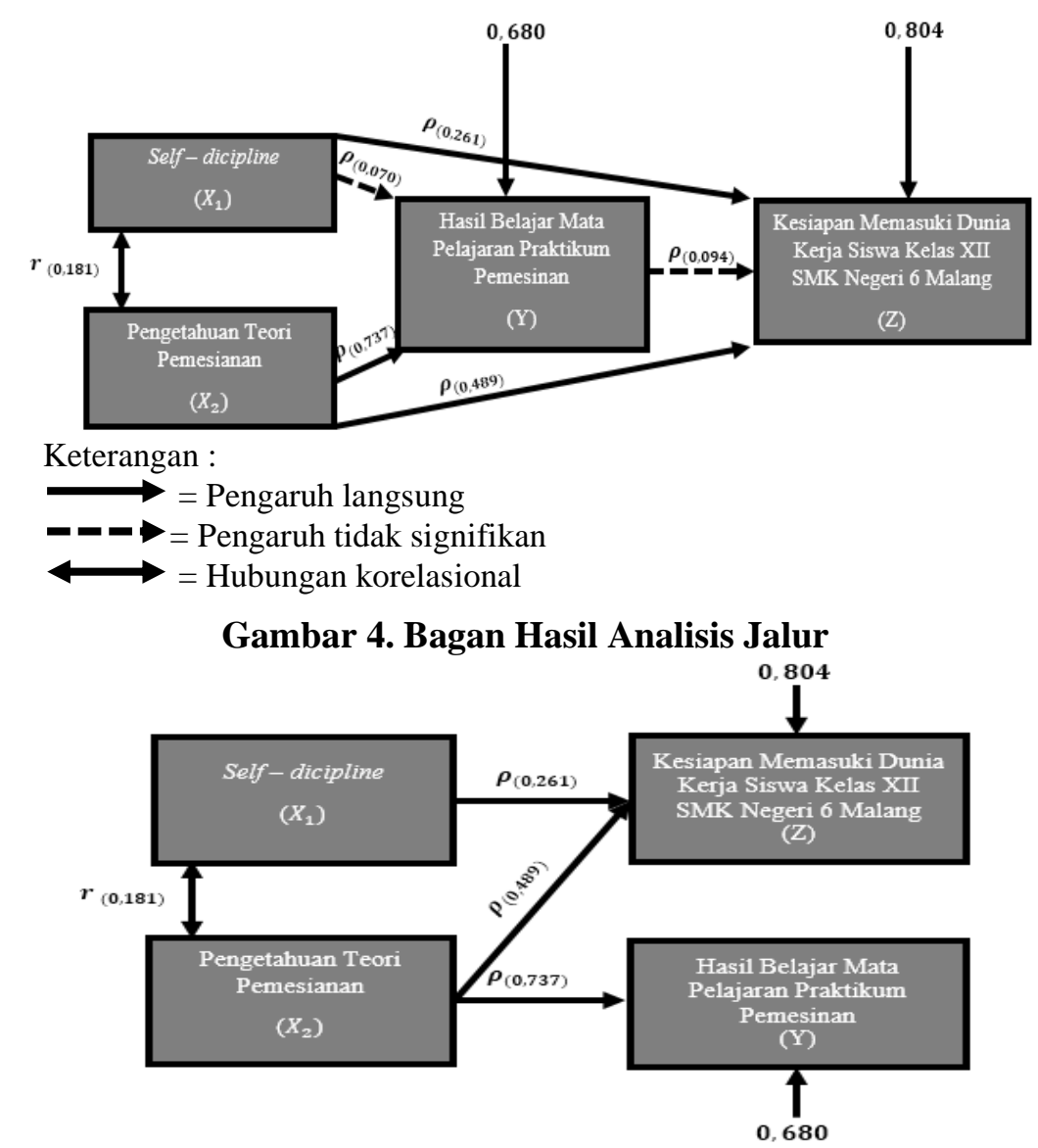

Gambar 5. Bagan Perbaikan Analisis Jalur

Tabel 9. Hasil Regresi Parsial Struktur Kedua

\begin{tabular}{lccc}
\hline \multirow{2}{*}{ Model } & \multicolumn{3}{c}{ Jalur Kausal 2 } \\
\cline { 2 - 4 } \multicolumn{1}{c}{ X1 } & X2 & Y \\
\hline B & 0,243 & 1,006 & 0,201 \\
Std. Error & 0,086 & 0,314 & 0,282 \\
Beta & 0,254 & 0,420 & 0,094 \\
Nilai t & 2,807 & 3,203 & 0,714 \\
Signifikansi & 0,006 & 0,002 & 0,478 \\
\hline
\end{tabular}

secara parsial dapat dilakukan. Hasil regresi parsial strutur kedua dapat dilihat pada Tabel 9. Karena jalur hubungan antara hasil belajar praktikum pemesinan dengan kesiapan memasuki dunia kerja tidak menunjukkan hasil yang signifikan, maka jalur tersebut dihilangkan dan dilakukan analisis ulang.

Hasil analisis ulang jalur 2 metode trimming terdapat pada Tabel 10. Hasil ini diketahui peningkatan koefisien jalur (beta) antar variabel $\mathrm{X} 1$ terhadap $\mathrm{Z}$ yaitu
Tabel 10. Hasil Regresi Parsial Jalur 2 Metode Trimming

\begin{tabular}{lcc}
\hline \multicolumn{1}{c}{ Model } & $\mathbf{X 1} \rightarrow \mathbf{Z}$ & $\mathbf{X 2} \rightarrow \mathbf{Z}$ \\
\hline$R$ square & 0,353 & 0,353 \\
Beta & 0,261 & 0,489 \\
Nilai $t$ & 2,904 & 5,441 \\
Signifikansi & 0,005 & 0,000 \\
\hline
\end{tabular}

sebesar 0,261 yang semula 0,254 dan peningkatan juga terjadi pada koefisien jalur X2 terhadap $\mathrm{Z}$ yaitu sebesar 0,489 dari semula 0,420 .

Penyederhaan jalur, berdasarkan hasil analisis koefisien jalur pada sub struktur pertama dan kedua setelah dilakukan metode trimming, dapat digambarkan secara keseluruhan bagan perbaikan jalur kausal antar variabel pada Gambar 4. Berdasarkan hasil trimming pada masing-masing jalur, maka dapat dibuat bagan hubungan yang lebih sederhana, dapat dilihat pada Gambar 5. 


\section{PEMBAHASAN}

Berdasarkan hasil analisis, ditemukan bahwa tidak terdapat pengaruh langsung yang signifikan antara variabel selfdiscipline dengan hasil belajar praktikum pemesinan. Besarnya pengaruh variabel self-discipline terhadap hasil belajar praktikum pemesinan yaitu 0,070 dengan nilai signifikansi 0,353 yang mana lebih besar dari alpha $(0,05)$. Hasil analisis yang ditunjukkan berlawanan dengan temuan Sholihat (2015:48) dengan hasil yaitu terdapat korelasi antara disiplin belajar dengan hasil belajar yang mana diperoleh koefisien path sebesar 0,171. Dengan demikian diperlukan kajian lebih mendalam terkait kontribusi self-discipline terhadap hasil belajar praktikum pemesinan.

Hasil belajar tidak dapat dilihat secara terpisah (fragmentasi) melainkan harus komperhensif. Hal tersebut didasarkan atas pemikiran para pakar pendidikan seperti Gagne (1965) yang merumuskan hasil belajar berupa hal-hal sebagai berikut: (1) informasi verbal; (2) keterampilan intelektual; (3) strategi kognitif; (4) keterampilan motorik; dan (5) sikap. Selain itu menurut Bloom, hasil belajar mencangkup kemampuan kognitif, afektif dan psikomotorik. Sedangkan menurut Lindgren hasil pembelajaran meliputi kecakapan, informasi, pengertian dan sikap.

Faktor-faktor yang menjelaskan tentang hasil belajar bukan hanya dari segi sikap saja, melainkan juga dari tingkat pengetahuan dan keterampilan siswa. Apabila dicermati self-discipline merupakan salah satu bagian kecil dari sikap yang harus dimiliki oleh siswa. Ditinjau dari kacamata pendidikan kejuruan bahwa program kejuruan teori diarahkan pada pencapaian kognitif, afektif, dan psikomotorik, sedangkan program kejuruan praktik diarahkan pada pencapaian tujuan yang bersifat psikomotorik.

Priyono (2010:5) menjelaskan bahwa kategori yang digunakan dalam mengukur keterampilan psikomotorik pada umumnya mencakup dua aspek yaitu kecermatan kerja dan kecepatan kerja. Dalam penelitian ini self-discipline masuk kedalam ranah afektif yang mana apabila dikaitkan dengan hasil belajar praktikum pemesinan masih kurang cocok, sebab self-dicipine berkaitan dengan disiplin belajar yang mengarah pada aspek pengetahuan siswa. Pernyataan tersebut di perjelas pada temuan Zhao dan Kuo (2015:67) bahwa self-discipline berpengaruh lebih tinggi pada ranah prestasi akademis yaitu dengan harga $\mathrm{R}^{2}$ sebesar 0,029 dari pada ranah perilaku $\left(\mathrm{R}^{2}=\right.$ $0,023)$ dan pengontrolan emosi $\left(\mathrm{R}^{2}=\right.$ 0,009 ).

Sejatinya sikap disiplin diri merupakan suatu kepribadian seseorang yang seharusnya ditumbuhkan sejak dini. Oleh karena itu lingkungan keluarga sebagai benteng pertahanan pertama bagi anak menjadi faktor utama dalam menumbuhkan sikap disiplin ini sebelum akhirnya dikembangkan lebih lanjut oleh lembaga sekolah. Penelitian yang dilakukan Rostam (2015:66) menemukan bahwa pendidikan orang tua dibarengi dengan self-discipline berpengaruh terhadap prestasi akademik siswa. Dengan demikian self-discipline merupakan faktor yang erat kaitannya dengan keluarga yang mana harus ditumbuhkan sejak dini dan nantinya terus dikembangkan melalui lembaga sekoah.

Berdasarkan hasil regresi parsial, ditemukan bahwa terdapat pengaruh yang cukup besar antara pengetahuan teori pemesinan terhadap hasil belajar praktikum pemesinan dengan nilai koefisien jalur sebesar 0,725 dan meningkat menjadi 0,737 setelah dilakukan perbaikan dengan metode trimming. Nilai signifikansi yang ditunjukkan juga berada dibawah 0,05 yaitu pada angka 0,000 . Dengan demikian dapat disimpulkan bahwa terdapat pengaruh yang signifikan antara pengetahuan teori pemesinan dengan hasil 
belajar praktikum pemesinan. Pernyataan tersebut diperkuat dengan temuan Sukardi, dkk. (2015) yang menyimpulkan bahwa terdapat hubungan antara pengetahuan teori terhadap prestasi praktik siswa SMK dengan nilai $\mathrm{R}$ sebesar 0,42 dan signifikan pada 0,000 .

Pada hakikatnya kegiatan praktikum memang tidak lepas dari adanya suatu teori/materi yang mendasari. Sesuai pernyataan Hariyanto (2015:79) bahwa teori menjadi bekal dan pedoman siswa dalam melaksanakan praktikum, sedangkan praktikum merupakan penerapan dari teori yang telah diterima oleh siswa. Dengan adanya teori, siswa akan menjadi tahu langkah-langkah yang tepat dalam melaksanakan praktikum. Semua teori pemesinan yang telah diajarkan tersebut akan berbaur dalam kegiatan praktikum pemesinan untuk menciptakan suatu produk yang berkualitas. Kegiatan praktikum juga dapat dijadikan sebagai tanda tingkat keberhasilan peserta didik dalam menguasai teori pemesinan. Ali dan Asrori (2014:7) menyatakan bahwa pengetahuan yang dimiliki oleh manusia ada kalanya diperoleh dari pengalaman dan pemikiran. Pengetahuan yang bersumber dari pengalaman adalah semua hal yang dialami oleh pancaindra. Dengan adanya praktikum, siswa memperoleh pengalaman secara langsung untuk menerapkan teori yang telah diajarkan sebelumnya.

Hasil temuan data menerangkan bahwa terdapat kontribusi yang signifikan $(0,006<0,05)$ antara variabel selfdiscipline terhadap kesiapan memasuki dunia kerja dengan nilai koefisien regresi parsial sebesar 0,254. Hasil analisis ulang pada sub struktur kedua menunjukkan koefisien jalur X1 terhadap Z meningkat menjadi 0,261 setelah dilakukan perbaikan dengan metode trimming. Dari hasil analisis dapat disimpulkan bahwa self-discipline mempengaruhi kesiapan memasuki dunia kerja.
Hasil analisis tersebut sesuai dengan temuan Saputra (2014:97) bahwa terdapat pengaruh positif antara sikap kerja siswa terhadap kesiapan kerja siswa yang ditunjukkan dengan maximum likelihood estimate sebesar 0,158 dengan taraf kepercayaan $95 \%$. Sedangkan menurut Rifai (2015) bahwa sikap softskill berpengaruh terhadap kesiapan kerja. Hasil temuan tersebut menunjukkan bahwa tinggi rendahnya sikap kerja siswa memberikan pengaruh terhadap perubahan kesiapan kerja siswa. Self-discipline termasuk kedalam aspek psikologi siswa yang mana merupakan faktor internal dari sikap kerja.

Dalam kenyataannya masih banyak perilaku menyimpang yang akhir-akhir ini tampaknya sungguh sangat mengkhawatirkan (Arsa dan Winahya, 2012: 155). Oleh sebab itu kematangan siswa untuk membentuk pola pikir dalam menentukan masa depannya mutlak diperlukan agar siswa lebih siap memasuki dunia kerja.

Pengetahuan teori pemesinan berpengaruh secara signifikan terhadap kesiapan siswa memasuki dunia kerja. Harga koefisien regresi parsial menunjukkan angka 0,420 dengan signifikansi 0,002 < 0,05 ; sedang setalah dilakukan perbaikan dengan metode triming, koefisien jalur meningkat menjadi 0,489 . Hasil tersebut senada dengan temuan Habibi (2012) yang mana menyimpulkan bahwa ada hubungan yang positif dan signifikan antara kompetensi akademik bidang produktif dengan kesiapan memasuki dunia kerja siswa SMK. Penelitian Saputra (2014:93) juga menemukan bahwa terdapat pengaruh positif dan signifikan antara prestasi belajar bidang produktif terhadap kesiapan kerja siswa dengan nilai maximum likelihood estimate sebesar 0,407 dengan taraf kepercayaan 95,00\%. Dengan demikian dapat diketahui bahwa tinggi rendahnya tingkat pengetahuan teori pemesinan siswa memberikan pengaruh terhadap kesiapan memasuki dunia kerja. 
Seseorang yang diterima kerja pada suatu perusahaan atau industri, dituntut untuk selalu menerapkan ilmu pengetahuannya ketika bekerja yang bertujuan supaya produk yang dikerjakan memuaskan dan sesuai dengan standar yang telah ditetapkan. Sebaliknya apabila seseorang kurang dalam menguasai teori atau konsep ketika bekerja, tentunya akan mengalami hambatan atau kesulitan sewaktu menyelesaikan pekerjaan yang ditugaskan kepadanya. Hal ini senada dengan temuan Dirwanto (2008:113) bahwa faktor yang mempengaruhi kesiapan kerja siswa SMK adalah segi pengetahuan.

Tuntutan dunia kerja salah satunya adalah calon pegawainya mampu melaksanakan pekerjaannya sesuai dengan teori dan konsep yang telah dipelajari, guna untuk mengurangi kesalahan dalam bekerja. Setiap individu memiliki tingkat pemahaman materi yang berbeda-beda yang mana semakin dia paham dan mengerti akan materi kejuruannya, maka semakin dia akan merasa yakin pada dirinya sendiri untuk siap terjun di dunia kerja.

Tidak terdapat pengaruh antara hasil belajar praktikum pemesinan dengan kesiapan siswa dalam memasuki dunia kerja. Harga koefisien jalur sebesar 0,094 dengan nilai signifikansi $0,487>0,05$. Dengan demikian tinggi rendahnya hasil belajar praktikum pemesinan tidak berpengaruh terhadap kesiapan siswa memasuki dunia kerja. Oleh sebab itu diperlukan kajian lebih mendalam terkait pengaruh hasil belajar praktikum pemesinan terhadap kesiapan siswa memasuki dunia kerja.

Chaplin (dalam Paramitha, 2015:37) mendefinisikan kesiapan sebagai tingkat perkembangan seseorang yang disebabkan oleh kematangan atau kedewasaan yang berpengaruh dalam mempraktikkan sesuatu. Kesiapan sejatinya tumbuh dalam diri seseorang yang bersifat naluriah, artinya seseorang dikatakan telah siap untuk melakukan sesuatu apabila telah merasa mampu menghadapi suatu hal. Menurut Supriyono (dalam As, 2014:14) terdapat dua indikator yang mempengaruhi kesiapan kerja, yaitu faktor internal dan faktor eksternal. Faktor internal meliputi mental, tekanan, kreativitas, minat, bakat, intelegensi, kemandirian, penguasaan ilmu pengetahuan, dan motivasi. Sedangkan faktor eksternal meliputi peran masyarakat, keluarga, sarana dan prasarana, informasi dunia kerja dan pengalaman prakerin.

Sejatinya hasil belajar pada praktikum pemesinan merupakan rentangan nilai siswa yang berupa angka-angka setelah mengikuti mata pelajaran praktikum pemesinan. Dalam hal ini diketahui bahwa sekalipun siswa mempunyai hasil belajar yang tinggi maupun rendah tidak mempengaruhinya untuk siap dalam memasuki dunia kerja. Pernyataan tersebut sejalan dengan temuan Zuhla (2016:46) yaitu hasil belajar siswa tidak berpengaruh secara signifikan terhadap kesiapan kerja siswa SMK di Kota Malang dengan nilai koefisien regresi sebesar 0,299 dan nilai signifikansi $0,790>0,05$. Oleh sebab itu kesiapan kerja siswa SMK tidak dipengaruhi oleh nilai akhir siswa.

\section{SIMPULAN DAN SARAN}

Berdasarkan hasil analisis dapat diambil kesimpulan sebagai berikut: (1) self-discipline tidak berpengaruh langsung terhadap hasil belajar praktikum pemesinan; (2) pengetahuan teori pemesinan berpengaruh langsung terhadap hasil belajar praktikum pemesinan, terutama setelah diadakan perbaikan jalur; (3) selfdiscipline berpengaruh langsung terhadap kesiapan memasuki dunia kerja; (4) pengetahuan teori pemesinan berpengaruh langsung terhadap kesiapan memasuki dunia kerja; (5) hasil belajar praktikum pemesinan tidak berpengaruh langsung terhadap kesiapan memasuki dunia kerja; dan (6) self-discipline dan pengetahuan 
teori pemesinan tidak berpengaruh secara tidak langsung terhadap kesiapan memasuki dunia kerja sebesar.

Berdasarkan kesimpulan disarankan kepada siswa untuk membiasakan berperilaku disiplin, meningkatkan pengetahuan tentang teori produktif dan ketika melaksanakan tugas untuk berperilaku layaknya telah bekerja di suatu industri. Guru dalam hal ini berperan sebagai fasilitator agar terus memperbaiki strategi pembelajarannya, pemberian tugas menyerupai di dunia kerja, disiplin waktu dan sikap. Sekolah sebagai penyelenggara pembelajaran, hendaknya lebih memperhatikan pengembangan sikap siswa melalui program-program kerja sekolah seperti: unit produksi, pengenalan dunia kerja, dan pelatihan sikap kerja di suatu industri. Bagi peneliti lain untuk lebih banyak mengkaji lebih dalam literatur-literatur yang berkaitan dengan kesiapan memasuki dunia kerja siswa di SMK.

\section{DAFTAR RUJUKAN}

Ali, M. \& Asrori, M. 2014. Metodologi \& Aplikasi Riset Pendidikan. Jakarta: Bumi Aksara.

Amri, S., Jauhari, A., \& Elisah, T. 2011. Implementasi Pendidikan Karakter dalam Pembelajaran. Jakarta: Prestasi Pustaka Publisher.

Arsa, I.M.R. \& Winahya, A.E. 2012. Evaluasi Pembelajaran Berbasis Karakter di Sekolah Menengah Kejuruan. Teknologi dan Kejuruan, 35(2): 155-162.

As, S. 2014. Kontribusi Motivasi untuk Bekerja dan Prestasi Belajar AUTOCAD terhadap Kesiapan Kerja Siswa di Bidang Jasa Konstruksi SMK Se-Malang Raya. Tesis tidak diterbitkan: Universitas Negeri Malang.

Dahar, R.W. 2011. Teori - teori Belajar dan Pembelajaran. Bandung: Erlangga.
Dirwanto. 2008. Analisis Faktor-faktor yang Mempengaruhi Kesiapan kerja pada Siswa SMK Ma'arif NU Kesesi Kabupaten Pekalongan Tahun Pelajaran 2007/2008. Tesis tidak diterbitkan. Surakarta. Universitas Sebelas Maret.

Gagne, R.M. 1965. The Conditions of Learning. New York: Holt, Rinehart and Winston. Inc.

Habibi. 2012. Hubungan Wawasan Dunia Kerja dan Kompetensi Akademik dengan Kesiapan Memasuki Dunia Kerja pada Siswa Kelas XII Program Studi Elektronika SMK di Malang. Skripsi tidak diterbitkan. Malang: Universitas Negeri Malang.

Hariyanto, D. 2015. Hubungan antara Pengetahuan Teori Teknik Pemesinan dan Kemampuan Praktik Teknik Pemesinan terhadap Kesiapan Praktik Kerja Industri Siswa Kelas XI SMK PGRI Wlingi Kabupaten Blitar. Skripsi tidak diterbitkan. Malang: Universitas Negeri Malang. Hariyanto, Sonhadji, A., \& Mizar, M.A. 2015. Hubungan Pelaksanaan Unit Produksi dan Motivasi Berwirausaha dengan Kesiapan Bekerja Siswa SMK. Teknologi dan Kejuruan, 38(1): 41-50.

Mulyasa. 2015. Pengembangan dan Implementasi Kurikulum 2013. Bandung: PT. Remaja Rosdakarya.

Nurhayati. 2015. Peningkatan Hasil Belajar Matematika Luas Segi Banyak melalui Model Student Fasilitator and Explaning. Jurnal Guru, 12(2): 173-181.

Paramitha, D.A. 2015. Kontribusi Pengalaman Praktik Unit Produksi, Soft Skill, dan Pengalaman Prakerin terhadap Kompetensi Siswa serta Dampaknya pada Kesiapan Kerja Siswa SMK Paket Keahlian Jasa Boga. Tesis tidak diterbitkan. Malang: Universitas Negeri Malang. 
Priyono. 2010. Pengaruh Struktur Penugasan dan Balikan terhadap Hasil Belajar Keterampilan Praktik Kerja Kayu. Tesis tidak diterbitkan. Malang: Universitas Negeri Malang.

Rifai, M. 2015. Kesiapan Soft Skills Siswa SMK N 5 Semarang untuk Memasuki Dunia Kerja. Skripsi tidak diterbitkan. Semarang: Universitas Negeri Semarang.

Rizkiansyah, Z. 2016. Hubungan antara Etika Kerja dalam Praktik Industri dan Kompetensi Kejuruan terhadap Kesiapan Kerja di Industri bagi Mahasiswa S1 Pendidikan Teknik Elektro Universitas Negeri Malang. Skripsi tidak diterbitkan. Malang: Universitas Negeri Malang.

Rostam, A.H. 2015. Anticipating Academic Progress of Students on the Basis of Self-Discipline and Demographic Variables. Mediterranean Journal of Social Sciences, 6(1): 6167.

Saleh, A.M. 2012. Membangun Karakter dengan Hati Nurani. Jakarta: Erlangga.

Saputra, S. 2014. Kontribusi Prestasi Belajar Bidang Produktif, Sikap Kerja, Kondisi Sosial Ekonomi Orang Tua, Minat Kerja terhadap Kesiapan Kerja Siswa SMK Negeri di Kabupaten Bulukumba Jurusan Teknik Komputer dan Jaringan. Tesis tidak diterbitkan. Malang: Universitas Negeri Malang.

Shochib, M. 2000. Pola Asuh Orang Tua untuk Membantu Anak Mengem- bangkan Disiplin Diri. Jakarta: PT Rineka Cipta.

Sholihat, R.I. 2015. Pengaruh Efektivitas Peraturan Sekolah dan Fasilitas Belajar terhadap Motivasi dan Disiplin Belajar serta Implikasikasi pada Hasil Belajar Siswa pada Mata Pelajaran IPS. Jurnal Penelitian Pendidikan, 15(3): 42-52.

Sukardi, Sunardi, \& Sampe, L. 2015. Hubungan Penguasaan Teori dengan Keterampilan Merangkai Kelistrikan Otomotif. Jurnal Teknologi dan Kejuruan, 38(1): 65-76.

Undang-Undang Republik Indonesia Nomor 20 Tahun 2003 tentang Sistem Pendidikan Nasional. 2003. Jakarta: Presiden Republik Indonesia.

Wibowo, N. 2015. Upaya Memperkecil Kesenjangan Kompetensi Lulusan Sekolah Menengah Kejuruan dengan Tuntutan Dunia Industri. Jurnal Pendidian Teknologi dan Kejuruan, 23(1): 45-50.

Zhao, R. \& Kuo, Y.L. 2015. The Role of Self-discipline in Predicting Achievement for $10^{\text {th }}$ Graders. International Journal of Intelligent Technologies and Applied Statistics, 8(1): 61-70.

Zuhla, I.L. 2016. Pengaruh Motivasi Berprestasi dan Hasil Belajar terhadap Kesiapan Kerja Siswa SMK Paket Keahlian Teknik Gambar Bangunan di Kota Malang. Skripsi tidak diterbitkan. Malang: Universitas Negeri Malang. 